\title{
THE EUROPEAN UNION AS A MANAGER OF GLOBAL 'BUSINESS AND HUMAN RIGHTS' REGULATION: COUNTRY-BY-COUNTRY REPORTING RULES
}

Aleydis Nissen*

\begin{abstract}
The European Union's 2013 Country-by-Country Reporting (CBCR) rules bring within the public domain information on corporate payments made to governments all over the world for the purpose of exploiting natural resources in the oil, gas, mining and logging sectors. In so doing, the CBCR rules enhance transparency in these sectors and aim to reduce tax avoidance and corruption in resource-rich countries. Arguably, they also contribute to the European Commission's long-term strategy to secure sustained access to raw materials in the European Economic Area. The CBCR rules represent one of the only three binding regulatory frameworks that have been adopted at the EU level to implement the 2011 UN Guiding Principles on Business and Human Rights. Just as with the two other initiatives that came into existence (the NonFinancial Reporting Directive and the Conflict Minerals Regulation), the immediate impact on the competitiveness of corporations based in the EU was a key concern during the legislative process. This article uncovers the two strategies that were employed to overcome such concern and give the CBCR rules a 'global' character.
\end{abstract}

\section{A. INTRODUCTION}

The Treaty of the European Union (TFEU) establishes that the European Union (EU) has the duty to promote human rights within the competences attributed by its Member States when it adopts and implements regulations as well as in its relations with the wider world. ${ }^{1}$ On this basis, the EU has taken a variety of actions to prevent and remedy human rights violations by corporate actors. ${ }^{2}$ However, it was the endorsement of the United Nations (UN) Guiding Principles by the UN Human Rights Council in 2011 that triggered the EU's more formal and focused approach to 'business and human rights' issues. ${ }^{3}$ The

\footnotetext{
${ }^{1}$ PhD student, School of Law and Politics, Cardiff University. Thanks to Lewis Graham, Urfan Khaliq, Joyman Lee, Shaun Matos, Andrew McLean, Steven Nam, Luminiţa Olteanu, Jiř́ Přibáň, Theo Raedschelders $\mathrm{Sr}$ and the reviewers. I would also like to use this opportunity to thank Joo-Young Lee and Stijn Smismans for their continued gratuitous support as well as Ludger Kühnhardt and Woo-Sik Moon for being so kind to host me at Bonn University's Zentrum für Europäische Integrationsforschung and Seoul National University's EU Centre while I was researching this article. All mistakes remain my own. Consolidated Version of the Treaty on European Union [2012] OJ C326/13, arts 2, 3(5) and 21(1).

${ }^{2}$ Stephanie Bijlmakers, Mary Footer and Nicolas Hachez, 'The EU's Engagement with the Main Business and Human Rights Instruments' (2015) <http://www.fp7-frame.eu/wpcontent/uploads/2016/09/Deliverable-7.4.pdf> accessed 29 February 201850.

${ }^{3}$ UNHRC, Res 17/4 (2011) UN Doc A/HRC/RES/17/4; EU Permanent Delegation to the UN Office and other International Organisations in Geneva, 'Business and Human Rights - Human Rights Council Resolution 17/4' (2012) D(2012) 703 034, 1; Commission, 'Staff Working Document on Implementing the UN Guiding Principles on Business and Human Rights - State of Play’ SWD (2015) 144 final 2.
} 
UN Guiding Principles serve as the basis to foster consistency in multilateral as well as unilateral initiatives in which the EU is involved in the 'business and human rights' area. ${ }^{4}$

A number of non-binding multilateral initiatives that have materialised following the adoption of the UN Guiding Principles were fully welcomed by the European Commission (Commission) and other EU institutions. ${ }^{5}$ These include the 2011 update of the Organisation for Economic Co-operation and Development's (OECD) Guidelines for Multinational Companies, the Office of the UN High Commissioner for Human Rights Accountability and Remedy Project and the Council of Europe's Committee of Ministers Recommendation on Human Rights and Business. ${ }^{6}$

The EU and its Member States also rely upon the UN Guiding Principles to justify not engaging constructively in the ongoing elaboration process on an international legally binding treaty at the UN Human Rights Council since 2014. ${ }^{7}$ While the UN Guiding Principles are applicable to all corporations, the treaty is predicted to have a more limited scope. Resolution A/HRC/RES/26/9, which triggered the treaty elaboration process, sets out that it would only be applicable to 'transnational corporations and corporations that have a transnational character in their operational activities'. ${ }^{8}$ The EU has criticised the UN Working Group leading the treaty elaboration process because it has not facilitated a broad and constructive dialogue regarding the scope of application of the future treaty,

\footnotetext{
${ }^{4}$ EU External Action Service, '2017 United Nations Forum on Business and Human Rights - EU Contribution' (2017) <https://eeas.europa.eu/headquarters/headquarters-homepage/36353/2017-unitednations-forum-business-and-human-rights-eu-contribution_en> accessed 11 February 2018.

${ }^{5}$ For example, Commission (n 3) 21; European Parliament, 'Resolution on the EU's Priorities for the UNHRC Sessions in 2016' (2016) 2015/3035(RSP) 27; Council of the EU, 'Council Conclusions on EU Priorities at UN HR fora in 2017' (2017) 5689/17, Annex para 27.

${ }^{6}$ Office of the High Commissioner for Human Rights, 'Background Paper Accompanying Draft Guidance Prepared by OHCHR for the Purposes of Inclusion in its Final Report to the Human Rights Council pursuant to $\mathrm{A} / \mathrm{HRC} / \mathrm{Res} / 22 / 26, \quad$ para $\quad 7$, (2015) $\quad<\mathrm{http}: / / \mathrm{www}$.ioeemp.org/fileadmin/ioe_documents/publications/Policy\%20Areas/business_and_human_rights/EN/_201602-22_C-362_OHCHR_Bus_Human_Rights_Accountability__Remedy_Project_-

_Background_Paper_to_draft_guidance_final_.pdf> accessed 24 March 2016; OECD, OECD Guidelines for Multinational Enterprises (2nd edn, OECD Publishing 2011); Council of Europe, 'Recommendation of the Committee of Ministers to Member States on Human Rights and Business' CM/Rec (2016) 3.

${ }^{7}$ EU, 'UN Human Rights Council $26^{\text {th }}$ Session - Item 3 Resolution L.22, EU Explanation of Vote' (2014) 〈https://www.globalpolicy.org/images/pdfs/GPFEurope/HRC_resolution_Explanation_of_vote_EU.pdf> accessed 11 November 2017.

${ }^{8}$ UNHRC, Res 26/9 (2014) UN Doc A/HRC/RES/26/9.
} 
including the meaning of 'having a transnational character'. ${ }^{9}$ For this reason, the EU Member States voted en bloc against Resolution A/HRC/RES/26/9 alongside the US. ${ }^{10}$

In so doing, the EU aimed to protect the competitiveness of EU-based corporations. It is indeed likely that the treaty would create an uneven playing field, which disadvantages EU-based corporations that operate in third countries where the domestic protection of human rights is weak. While the EU finally started engaging in the treaty elaboration process in 2016 under pressure from the European Parliament, ${ }^{11}$ the EU's participation remains largely restrained. ${ }^{12}$ Most recently, at the fourth session of the Working Group in October 2018, the EU and its Member States were not prepared to exchange views with the civil society on how the future treaty could build on existing EU initiatives in the area of business and human rights.

Bearing in mind these observations relating to the EU's position in the ongoing treaty process, the question arises whether the EU has been able to mitigate the effects on the competitiveness of EU-based corporations in mandatory unilateral initiatives, which fit in with its approach to 'business and human rights' issues. To date, three EU regulatory frameworks have come into existence, which contribute to the implementation of the UN Guiding Principles. ${ }^{13}$ These are the sector-wide 2014 Non-Financial Reporting Directive and two regulatory frameworks that specifically target raw materials, the 2013 CBCR rules and the 2017 Conflict Minerals Regulation. ${ }^{14}$

\footnotetext{
9 European Parliament, 'Research Initiative Towards a Binding International Treaty on Business and Human Rights' (2018) PE 620.229 11.

${ }^{10}$ EU, 'UN Human Rights Council 26 ${ }^{\text {th }}$ Session - Item 3 Resolution L.22, EU Explanation of Vote' (2014) <https://www.globalpolicy.org/images/pdfs/GPFEurope/HRC_resolution_Explanation_of_vote_EU.pdf> accessed 11 February 2018. See Nicole Tuttle, 'Human Rights Council Resolutions 26/9 and 26/22: Towards Corporate Accountability' (2015) 19 American Society of International Law Insights <https://www.asil.org/insights/volume/19/issue/20/human-rights-council-resolutions-269-and-2622towards-corporate $>$ accessed 5 February 2016.

${ }^{11}$ European Parliament, 'Resolution of 21 January 2016 on the EU's Priorities for the UNHRC Sessions in 2016' (2015) 2015/3035(RSP) para 28; European Parliament, 'Resolution of 14 December 2016 on the Annual Report on Human Rights and Democracy in the World and the European Union's policy on the matter 2015' (2016) 2016/2219(INI) para 84; European Parliament, 'Resolution of 25 October 2016 on Corporate liability for Serious Human Rights Abuses in Third Countries' (2016) 2015/2315(INI) para 12.

12 European Parliament, 'Research Initiative Towards a Binding International Treaty on Business and Human Rights' (2018) PE 620.229, 11.

${ }^{13}$ As noted in Commission (n 3) 10; EU External Action Service, '2016 United Nations Forum on Business and Human Rights - Contribution of the European Union' (2016) <https://eeas.europa.eu/headquarters/headquarters-homepage/14906/2016-united-nations-forum-businessand-human-rights-contribution-european-union_en> accessed 11 February 2018; EU External Action Service (n 4).

14 European Parliament and Council Directive 2014/95/EU of 22 October 2014 Amending Directive 2013/34/EU as regards Disclosure of Non-Financial and Diversity Information by Certain Large Undertakings and Groups Text with EEA relevance [2014] OJ L330/1 (Directive 2014/95/EU); Directive
} 
They have been coordinated through the Commission's Corporate Social Responsibility (CSR) Strategy. The 2011-2014 CSR Strategy is the Commission's first Strategy in which it has stated that mandatory regulation might be needed in order to make CSR an integral part of corporations' core strategic thinking. ${ }^{15}$ To this end, a new definition of CSR, consistent with the UN Guiding Principles (and other CSR principles and guidelines), has been set out by the Commission. Accordingly, CSR is understood as 'the responsibility of enterprises for their impacts on society'. ${ }^{16}$ More specifically, the Commission indicated that 'a smart mix of voluntary policy measures and, where necessary, complementary regulation' would be required to implement CSR, including 'business and human rights' measures. ${ }^{17}$ This new approach can be considered a major change, even though the main responsibility to implement the Commission's CSR Strategy is attributed to corporations. Up until 2011, the Commission's CSR strategy provided a full-blown 'business case' which assumed that there would be sufficient incentives for corporations to adopt CSR measures voluntarily. CSR had previously been defined in the Commission's 2001 Green Paper as 'a concept whereby companies integrate social and environmental concerns in their business operations and in their interactions with their stakeholders on a voluntary basis'. ${ }^{18}$ This proposition had been justified by the Commission based on the argument that a strategic approach to human

2013/34/EU of 26 June 2013 on the Annual Financial Statements, Consolidated Financial Statements and Related Reports of Certain Types of Undertakings, Amending Directive 2006/43/EC of the European Parliament and of the Council and Repealing Council Directives 78/660/EEC and 83/349/EEC Text with EEA Relevance [2013] OJ L182/19 (Directive 2013/34/EU) art 51; Directive 2004/109/EC of the European Parliament and of the Council on the Harmonisation of Transparency Requirements in Relation to Information about Issuers whose Securities are Admitted to Trading on a Regulated Market [2004] OJ L390/38 amended by art 1 Directive 2013/50/EU European Parliament and Council Directive 2013/50/EU of 22 October 2013 amending Directive 2004/109/EC of the European Parliament and of the Council on the Harmonisation of Transparency Requirements in Relation to Information About Issuers whose Securities are Admitted to Trading on a Regulated Market, Directive 2003/71/EC of the European Parliament and of the Council on the Prospectus to be Published when Securities are Offered to the Public or Admitted to Trading and Commission Directive 2007/14/EC Laying down Detailed Rules for the Implementation of Certain Provisions of Directive 2004/109/EC Text with EEA relevance [2013] OJ L294/13 (Directive 2004/109/EC amended by art 6 Directive 2013/50/EU); European Parliament and Council Regulation 2017/821 of 17 May 2017 Laying down Supply Chain Due Diligence Obligations for Union Importers of Tin, Tantalum and Tungsten, their Ores, and Gold Originating from Conflict-Affected and High Risk Areas [2017] OJ L130/1.

15 Commission, ‘A Renewed EU Strategy 2011-14 for Corporate Social Responsibility' (2011) COM (2011) 0681 final 5; EU External Action Service (n 4).

16 Commission (n 15) 6.

17 ibid 10.

${ }^{18}$ Commission, 'Green Paper - Promoting a European framework for CSR' (Communication) COM (2001) 366 final 20. 
rights can result in a range of long-term benefits for corporations including a more committed workforce and a better reputation. ${ }^{19}$

This shift in favour of binding CSR rules makes the Commission's approach to CSR more congruent with the approach of the European Parliament. The latter body has pressured the Commission for decades to take binding CSR measures. In the 1990s, it noted already that 'codes of conduct must not be used as instruments for putting multinational enterprises beyond the scope of governmental and judicial scrutiny'. ${ }^{20}$ Corporations are indeed, in many instances, reluctant to implement voluntarily CSR measures, including those relating to human rights. While there is some room for differentiation regarding the impact of respecting or disrespecting CSR on the competitive advantage of corporations, investing in CSR capabilities generally does not 'pay off' immediately. Business organisational behaviour, therefore, tends to be rigid and resistant to change. The impact assessment of the 2014 Non-Financial Reporting Directive aptly noted in this regard that 'the benefits related to non-financial disclosure are often perceived as long-term and uncertain, while short-term costs are relatively high and easily measurable'. ${ }^{21}$

Through an in-depth investigation of a wide variety of documents of the relevant EU bodies and national actors, this article uncovers how the EU has handled concerns about competitiveness by giving the unilateral initiatives which fit in with its approach to 'business and human rights' issues a 'global' character. Due to space limitations, the analysis will focus mainly on the Country-by-Country Reporting (CBCR) rules.

The article is organised as follows. Section B describes the CBCR rules. Section C sets out why this unilateral initiative has been prioritised within the EU's approach to 'business and human rights' issues. It is argued that this initiative fits within the EU's long-term interests, which became a major concern after the 2007 global financial crisis. Section D discusses the scope of the CBCR rules and, in so doing, sets out the first

\footnotetext{
19 ibid para 24.

${ }^{20}$ European Parliament, Resolution on EU standards for European Enterprises Operating in Developing Countries: Towards a European Code of Conduct of 14 April 1999 [1999] OJ C 104180 recital F. See Jan Wouters and Leen Chanet, 'Corporate Human Rights Responsibility: A European Perspective' (2008) 6(2) Northwestern Journal of International Human Rights 272-83 for an overview of such calls by the European Parliament.

${ }^{21}$ Commission, 'Staff Working Document Executive Summary of the Impact Assessment Accompanying the document Proposal for a Directive of the European Parliament and of the Council amending Council Directives 78/660/EEC and 83/349/EEC as regards Disclosure of Non-Financial and Diversity Information by Certain Large Companies and Groups' SWD (2013) 0128 final 2.1.
} 
strategy used by the EU to give the CBCR rules a 'global' character. It highlights that the CBCR rules are applicable to certain categories of corporations based outside the European Economic Area (EEA). Section E discusses a second strategy that has been employed by the EU to give the CBCR rules a 'global' character. In particular, it shows that the EU aims to empower the multilateral Extractive Industries Transparency Initiative (EITI), which requests governments to publish the revenues actually received from corporations. It is further highlighted that, in achieving this goal, the EU attempts to bypass national governments. The final section F concludes and refers to the Conflict Minerals Regulation and the Non-Financial Reporting Directive.

\section{B. THE EU'S CBCR RULES}

The CBCR rules bring within the public domain information on corporate payments made to governments all over the world for exploiting natural resources in the extractive - oil, gas, mining - or logging (of primary forest) sectors. Certain corporations, which are active in these sectors, are required to disclose the total amount of annual corporate payments to each government all over the world and the projects concerned. In particular, they have to disclose their material payments to governments passing a de minimis threshold of EUR 100,000 within a financial year for national resources in a separate report on an annual basis. ${ }^{22}$ This regime includes not only taxes on income, production and profits but also other payments to governments such as royalties and payments for infrastructure improvements. ${ }^{23}$ The payments need to be broken down according to their type, on a country-by-country and project-by-project basis. ${ }^{24}$ The operational activities that are governed by a single contract, licence, lease, concession or a similar legal agreement and form the basis for payment liabilities to a government are defined as one project. ${ }^{25}$ If multiple agreements are substantially interconnected, then they will also be considered as one project. While such a definition is open to interpretation, ${ }^{26}$ activities

\footnotetext{
22 Arts 42-44 Directive 2013/34/EU.

23 Other payments that fall under the CBCR rules are production entitlements, royalties, dividends paid in lieu of such entitlements and royalties, signature, discovery and production bonuses, rental fees, entry fees and other considerations for licences and/or concessions. Taxes levied on consumption such as value added taxes, personal income taxes or sales taxes and dividends that have been paid to a government as a common or ordinary shareholders on the same terms as other shareholders do not need to be reported (Recital 48, arts 42(1) and 41(5) Directive 2013/34/EU).

${ }^{24}$ Art 43(2) Directive 2013/34/EU.

25 ibid art 41(4).

26 This makes it difficult to compare country-by-country reports. See Lucas Porsch and others, 'Study: Review of country-by-country reporting requirements for extractive and logging industries' (2018)
} 
that would otherwise fall under the Directive may not be re-characterised, artificially split or aggregated with a view to eluding the $\mathrm{CBCR}$ requirements according to the preamble. ${ }^{27}$

The information on payments needs to be made publicly available to all stakeholders through either the stock market information repository or the business registry in the same way as financial statements are made available. A copy of the whole or any part of the country-by-country report must be obtainable on application. ${ }^{28}$ The responsible bodies of a corporation such as the board of directors and C-level executives need to ensure that, to the best of their ability and knowledge, the report on payments to governments is drawn up and published. ${ }^{29}$ In case of non-compliance, national competent authorities or courts are entitled to impose fines. ${ }^{30}$ These penalties must be effective, proportionate and dissuasive.

\section{THE EU'S GOALS AND INTERESTS}

The legal basis of the CBCR rules is article 50 of the TFEU. This article sets out that the EU and its Member States share the competence to install necessary safeguards to protect shareholders and other stakeholders in order to attain the freedom of establishment of corporations within Member States. ${ }^{31}$ The protection of shareholders under article 50 TFEU has often been used as a basis to legitimise harmonising measures which enhance transparency and legal certainty in financial information. Shareholders need information such as the identity of other shareholders and the size of their shareholdings in order to make substantiated and well-conceived investment decisions. ${ }^{32}$ Relying upon this article to harmonise non-financial measures is, however, relatively new. ${ }^{33}$ It was the European

\footnotetext{
<https://ec.europa.eu/info/publications/181126-country-by-country-reporting-extractive-loggingindustries-study_en> accessed 26 June 2019 27-28.

${ }^{27}$ Recital 49 Directive 2013/34/EU.

28 ibid art 45(1).

29 ibid art 45(2).

30 ibid art 51; Art 6 Directive 2004/109 EC (amended by art 1 Directive 2013/50/EU).

31 Arts 50(1) and 50(2)(g) TFEU.

32 See Karsten Engsig Sørensen, 'Shareholders' Duty to Disclose' in Hanne Birkmose, Shareholders' Duties (Wolters Kluwer 2017) 307-08.

33 Art 50 TFEU had also been used as a basis to adopt the Non-Financial Reporting Directive, one of the three other binding EU regulatory frameworks that implement the UN Guiding Principles. This Directive encourages long-term shareholder engagement. Sustainable finance became a strategic priority for the Commission in the aftermath of the 2007 global financial crisis, which had a profound impact on the Eurozone. Institutional investors and asset managers were found to have supported market volatility and systemic risk by failing to account for material non-financial issues (such as respect for human rights). See European Commission, European Parliament, Council, European Economic and Social Committee and Committee of the Regions, 'Action Plan: European Company Law and Corporate Governance - a Modern
} 
Parliament that acknowledged the importance of corporations divulging CSR information with a view to identifying risks and increasing stakeholder trust in two separate 2013 Resolutions. ${ }^{34}$

The CBCR rules aim to improve the transparency of payments made to governments by oil, gas, mining and logging corporations. ${ }^{35}$ The trade in natural resources is often the cause or catalysing factor in conflicts in resource-rich countries. ${ }^{36}$ Potential revenues generated from these scarce resources are an important source of income for financing activities of governments, armed groups and security forces. The desire for control over natural resources is often accompanied by struggles over power, influence and related issues such as access to land and questions of identity and citizenship. For this reason, access to natural resources can be said to be inseparable from violence, corruption and human rights violations. ${ }^{37}$

The CBCR rules can indirectly provide affected populations of resource-rich countries with information regarding transactions of natural resources. The disclosed information might help citizens and civil society organisations in resource-rich countries to evaluate whether receipts from exploitation of natural resources deliver adequate value to them and to demand such value from their government if the evaluation returns a negative result (provided that they have the freedom to do so).$^{38}$ Increased public scrutiny and engagement can contribute to disseminating the information available and can provide clearer expectations concerning its materiality and completeness. This can, in

Legal Framework for More Engaged Shareholders and Sustainable Companies' (2012) COM/2012/0740 final.

${ }^{34}$ Recital 3 Directive 2014/95/EU referring to the European Parliament, 'Resolution of 6 February 2013 on Corporate Social Responsibility: Accountable, Transparent and Responsible Business Behaviour and Sustainable Growth' (2013) 2012/2098(INI) and to European Parliament, 'Resolution of 6 February 2013 on Corporate Social Responsibility: Promoting Society's Interests and a Route to Sustainable and Inclusive Recovery' (2013) 2012/2097(INI).

35 EU, 'Public Country-by-Country Reporting' <https://ec.europa.eu/info/business-economyeuro/company-reporting-and-auditing/company-reporting/public-country-country-reporting_en> accessed 11 September 2018.

${ }^{36}$ For a comprehensive review of the literature on the 'resource curse' see Jeffrey Frankel, 'The Natural Resource Curse: a Survey' (2010) NBER Working Paper Series $<$ http://www.nber.org/papers/w15836.pdf> accessed 11 September 2018.

${ }^{37}$ European Parliament, 'Resolution of 26 February 2014 on Promoting Development through Responsible Business Practices, including the Role of Extractive Industries in Developing Countries' (2014) 2013/2126(INI), 43.

${ }^{38}$ Commission, 'Staff Working Document Impact Assessment for Financial Disclosures on a Country-byCountry Basis Accompanying the Document Proposal for a Directive of the European Parliament and of the Council amending Council Directive 2004/109/EC on the Harmonisation of Transparency Requirements and Proposal for a Directive of the European Parliament and of the Council on the Annual Financial Statements, consolidated Financial Statements and Related Reports of Certain Types of Undertakings' SEC (2011) 1289 final 34. 
turn, lead to the development of comprehensive valuation models, including corporate responsibility to respect human rights. ${ }^{39}$ Increased public scrutiny can also, in the long run, encourage shareholders to assess and account appropriately for all the risks and externalities of firms. ${ }^{40}$

Over the years, the EU has often presented itself as a 'civilian' or 'normative' power which prioritises the values of respect for human dignity, freedom, democracy, equality, the rule of law and respect for human rights over self-interests. ${ }^{41}$ Such 'power' has been used by the EU to create a 'sense of common responsibility and structures of contractual politics' between state actors in international affairs. ${ }^{42}$ Manners argues that this was a way for the EU to legitimise and present itself as more than 'merely' a form of economic government in response to the increasing resistance by its citizens to economic liberalisation after the Cold War. ${ }^{43}$ However, the robustness and coherence of this identity in EU's relations with the wider world has been extensively criticised in the literature. ${ }^{44}$ It has been determined by now that the EU's normative interests are often subjugated to or influenced by its economic interests and other strategic interests such as regional stability and its geopolitical and commercial gain. ${ }^{45}$

The Commission indicated in its 2011-2014 CSR Strategy that the following three 'business and human rights' issues would require mandatory measures: to promote transparency; to create market incentives for responsible business conduct and to ensure corporate accountability. ${ }^{46}$ The Commission promised to share specific priorities regarding its 'business and human rights' agenda by the end of $2012 .{ }^{47}$ Yet, the Council

\footnotetext{
${ }^{39}$ Recital 3 Directive 2014/95/EU.

${ }^{40}$ European Commission (n 21) 6.1.4. See European Parliament and Council Directive 2017/828 of 17 May 2017 amending Directive 2007/36/EC as regards the Encouragement of Long-Term Shareholder Engagement [2017] OJ L 132/1, 2.

41 François Dûchene, 'The European Community and the Uncertainties of Interdependence' in Max Kohnstamm and Wolfgang Hager, A Nation Writ Large? Foreign-Policy Problems before the European Community (Palgrave Macmillan 1973) 1, 19-21; Ian Manners, 'Normative Power Europe: A Contradiction in Terms' (2002) 40(2) Journal of Common Market Studies 235, 244.

42 Dûchene (n 41).

43 Manners (n 41) 244.

${ }^{44}$ For example, Adrian Hyde-Price, 'Normative Power Europe: A Realist Critique' (2006) 13(2) J.E.P.P. 217; Lena Partzch, 'The New EU Conflict Minerals Regulation: Normative Power in International Relations' (2018) Global Policy 479.

45 There exists a rich literature on this topic. For example, Chad Damro, 'Market power Europe' (2012) 19(5) J.E.P.P. 682; Erik Oddvar Eriksen, 'The EU - a Cosmopolitan Polity?' (2006) 13(2) J.E.P.P. 252.

${ }^{46}$ Commission (n 15) 5; EU External Action Service (n 4).

${ }^{47}$ Commission (n 15) title 4.8.2 paras 11 and 12.
} 
of the EU correctly established that such priorities have not been communicated. ${ }^{48}$ The Council and the European Parliament have requested to put a number of other issues on the 'business and human rights' agenda, including responsible global value chains, child labour and access to civil judicial remedies. ${ }^{49}$ To date, these requests have been ignored by the Commission.

A likely reason for prioritising the CBCR rules within EU's approach to 'business and human rights' issues is that the normative interests at stake coincide with the strategic goal to secure access to raw materials. The CBCR rules and their impact assessment support this hypothesis. They refer to the need to secure access to oil and gas as well as EU's 'Forest Law Enforcement and the Governance and Trade' (FLEGT) Action Plan. ${ }^{50}$ On the one hand, securing access to oil and gas under the same conditions as industry competitors became a priority for the Commission after the disputes between Russia and Ukraine in 2006 and 2009 left six EU Member States - which depended on Russia as the single external supplier for their gas supply - with severe shortages. ${ }^{51}$ On the other hand, the FLEGT Action Plan implements a licensing scheme designed to guarantee that only legally harvested timber from partner countries that agree to take part in this scheme enter the EU. It is part of EU's Raw Materials Initiative, adopted in 2008 with a view to promoting access to non-energy materials that are crucial to the long-term sound functioning of EU industries, and hence to economic growth and jobs in the long run. ${ }^{52}$ The supply risks in the EU are mainly caused by resource concentration in combination with political and economic instability in a number of resource-rich countries. These risks are compounded by low substitutability in the EU and the rise of East and South Asian economies.

\section{A GLOBAL CHARACTER: EXTENSIVE SCOPE}

\footnotetext{
48 Council of the EU, 'Council conclusions on the Action plan on Human Rights and Democracy 20152019' (2015) 10897/15 action 18b.

${ }^{49}$ For example, Council of the EU, 'Council Conclusions on Child Labour' (2016) 10244/16; Council of the EU, 'Council Conclusions on Responsible Global Value chains' (2016) 8833/16; Council of the EU, 'Conclusions on Business and Human Rights of 20 June 2016' (2016) 10254/16 para 12, 15 and 26; European Parliament, 'Resolution of 21 January 2016 on the EU's Priorities for the UNHRC Sessions in 2016' (2016) 2015/3035(RSP) para 27

${ }^{50}$ Recitals 44 and 52 Directive 2013/34/EU; Recital 7 Directive 2013/50/EU and Commission (n 38) 40 referring to the European Commission, 'Forest Law Enforcement, Governance and Trade (FLEGT) Proposal for an EU Action Plan' COM (2003) 0251 final.

${ }^{51}$ Commission, ‘European Energy Security Strategy' COM (2014) 330 final 2.

${ }^{52}$ Commission, 'The Raw Materials Initiative Meeting Our Critical Needs for Growth and Jobs in Europe' COM (2008) 699 final 5.
} 
The CBCR rules fit into global efforts to regulate the exploitation of raw materials by corporate actors. Prior to EU's efforts, the United States (US) had already presented itself as a norm innovator in the regulation of raw materials. Under the Obama Administration, the US had questioned the international 'status quo' through the 2010 Dodd-Frank Wall Street Reform and Consumer Protection Act (US Dodd-Frank Act). Section 1504 of this Act required corporations, including non-US corporations, operating in the 'commercial development of oil, natural gas, or minerals' which have securities listed on US stock exchanges to publicly report payments to governments on a country- and project-specific basis. ${ }^{53}$ At the time, President Obama's Under Secretary for Economic Growth, Energy and the Environment at the State Department Catherine Novelli wrote that this legal requirement would allow the US to strengthen its credibility and ability to fight corruption. ${ }^{54}$

Both the EU and the US have tried to give their regulations a 'global' character by defining the scope of their rules in an extensive way. Just as section 1504 of the US Dodd-Frank Act is applicable to US listed corporations, EU's CBCR rules cover a broad scope. The CBCR rules are applicable to corporations which are listed on EEA regulated markets even if they are not incorporated under the laws of an EEA Member State. To this end, both the Accounting Directive 2013/34/EU and the Transparency Directive 2004/109 EC were changed. ${ }^{55}$ All corporations listed in the EEA, regardless of where they are incorporated, would have to comply with CBCR rules. For example, the China Petroleum \& Chemical Corporation (Sinopec) - which has been simultaneously listed on the Hong Kong, New York and London Stock Exchanges - has to comply with section 1504 of the US Dodd-Frank Act and EU's CBCR rules.

\footnotetext{
${ }^{53}$ Commission (n 38) 10-11. Stock exchanges are also increasingly setting standards for risk management. The UK Alternative Investment Market - a non-regulated stock market for smaller enterprises within the London Stock Exchange - and the Hong Kong Stock Exchange's Growth Market Enterprises have created CBCR obligations for new applicants that operate in the extractive sector See Commission (n 38). The London Metal Exchange is now considering to require copper-cobalt producers which source copper-cobalt from the DR Congo to carry out independent audits to prove their material is ethically sourced following its own investigation regarding the use by listed Chinese electronics corporations of copper-cobalt extracted from Congolese mines that use child labour (Lokin-Sassen in Nederland (Eerste Kamer der Staten Generaal) Dossier 34506 (19) Handelingen 19 December 2017, EK 2017-2018, 13, <https://zoek.officielebekendmakingen.nl/dossier/34506/h-ek-20172018-13-

19? resultIndex $=2 \&$ sorttype $=1 \&$ sortorder $=4>$ accessed 14 April 2018; Henry Sanderson, 'LME to strengthen scrutiny of DRC-sourced cobalt' Financial Times (2 July 2018) <https://www.ft.com/content/efe02b92-7b7f-11e8-8e67-1e1a0846c475> accessed 2 February 2018).

${ }^{54}$ Department of State Under Secretary for Economic Growth, Energy and the Environment (US), 'Letter to Mary Jo White, US Securities and Exchange Commission 21 January 2016' <https://www.sec.gov/comments/s7-25-15/s72515-13.pdf> accessed 27 June 20191.

${ }^{55}$ Art 42(1) Directive 2013/34/EU; Art 6 Directive 2004/109 EC (amended by art 1 Directive 2013/50/EU).
} 
While section 1504 of the US Dodd-Frank Act is only applicable to listed corporations, EU's CBCR rules also cover 'large' unlisted corporations in the EEA that pass a de minimis average threshold of 500 employees and either a balance sheet total of over EUR 20 million or a net turnover of over EUR 40 million during the relevant financial year. ${ }^{56}$ Corporations listed in the EEA successfully lobbied to extend the CBCR rules to large unlisted corporations registered in the EEA in order to ensure a level playing field on which listed and unlisted corporations share the same regulatory burden. It was reasoned that unlisted corporations also engage in cross-border activities and operate in countries other than their country of registration through subsidiaries, associates, joint ventures and branches. Not requiring CBCR information of unlisted corporations registered in the EEA might make it less attractive to be listed. This might have the consequence that less additional capital can be raised which might, in turn, become detrimental for economic growth and job creation.

This broadly defined scope can also indirectly affect unlisted companies headquartered in third countries. This is because any large subsidiaries of unlisted (and other) companies with legal personality in the EEA are subject to the reporting obligation on their behalf. Excluded from the CBCR rules are non-EEA corporations that have no large subsidiaries with legal personality in the EEA (and which are not listed in the EEA). This was a key concern during the legislative process. The Danish Minister of Economic and Business Affairs Brian Mikkelsen stressed in this regard that: "Any possible regulation should be done globally - partly to achieve the wanted effect, partly to protect against unfair competition. ${ }^{57}$ Two specific issues - which have previously also been raised in the US - were noted. ${ }^{58}$ First, the risk that there may be instances when commercially sensitive company information would be deduced from CBCR data was raised, including information on levels of turnover, pricing, costs and profit structure in a

\footnotetext{
${ }^{56}$ Arts 3(4), 42(1) and 42(2) Directive 2013/34/EU; Commission (n 38) 5-6.

${ }^{57}$ Ministry for Economic and Business Affairs (Denmark), 'Letter to European Commission 22 December 2010. Questionnaire: Country-by-Country Reporting by Multinational Companies' <http://www.regnskabsmail.dk/oldsite/Lovgivning/Udvalgsbilag/2010-11/ERU\%20bilag\%20103.pdf> accessed 9 November 2017.

58 Michel Barnier (in his capacity as Commissioner for Internal Market and Services), 'The EU Transparency and Accounting Directives' (2014) 7(1) Journal of World Energy Law and Business 16, 17. See US SEC, 'Disclosure of Payments by Resource Extraction Issuers' (2016) <https://www.sec.gov/rules/final/2016/34-78167.pdf> accessed 28 June 2019 111-13.
} 
third country. ${ }^{59}$ Second, the risk that EU corporations would no longer qualify as contract partners for governments around the world was considered troublesome.

It would be extremely controversial if the EU were to impose externally applicable rules on non-EU corporations that do not have a proximate connection with the EU. Instead, the Commission downplayed the two risks to which corporations that fall under the CBCR rules are exposed. Regarding the first issue, the impact assessment sets out that payments to governments represent only one element of a corporation's operating cost base. ${ }^{60}$ This seems to be correct and finds support in the fact that country-by-country reports do not need to be audited under the CBCR rules. ${ }^{61}$ There remains, however, a reasonable risk that project-level disclosure can result in disclosure of commercially sensitive information provided in respect of individual mines and oil fields if a corporation has only one project in a country. ${ }^{62}$ Second, it was considered that the risk that EU corporations would lose contracts would be negligible because they possess a number of unique qualities - such as engineering know-how and technical efficiency that corporations based in economically developing and emerging countries do not have. ${ }^{63}$ For example, while state-owned oil corporations in these countries far outnumber EU and US privately-owned corporations when measured in ownership of reserves, the latter group is far ahead in terms of capital expenditure. ${ }^{64}$

\footnotetext{
${ }^{59}$ Commission (n 38) 6, 8 and 38; European Commission (Directorate General for the Internal Market and Services), 'Summary Report of the Responses Received to the Commission's Consultation on Country-byCountry Reporting by Multinational Companies' (2011) 10 <http://ec.europa.eu/finance/consultations/2010/financial-reporting/docs/consultation_summary_en.pdf> accessed 12 February 2018.

${ }^{60}$ Commission (n 38) 25.

61 Art 45(1) Directive 2013/34/EU.

62 Repsol, 'Response to the Commission's Consultation on Country-by-Country Reporting by Multinational Companies' $\quad$ (2011) nr 2 <http://ec.europa.eu/yourvoice/ipm/forms/dispatch?userstate=View\&id=605444800501 > accessed 11 February 2018; Statoil, 'Response to the Commission's Consultation on Country-by-Country Reporting by

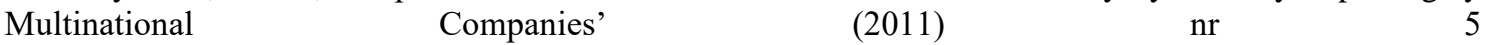
<http://ec.europa.eu/yourvoice/ipm/forms/dispatch?userstate=printcase\&id=866987818> accessed 11 February 2018.

63 Commission (n 38) 26, 39.

64 ibid 39-40 referring to Donald Losman, 'The Rentier State and National Oil Companies: An Economic and Political Perspective' 46(3) Middle East Journal (2010), 427, table 5; Amy Myers Jaffe, 'The Changing Role of National Oil Companies: Introduction and Summary Conclusions' (2007) James Baker III Institute for Public Policy of University 1 <http://large.stanford.edu/publications/coal/references/baker/studies/noc/docs/BI_Study_35-1.pdf> accessed 11 February 2018.
} 
A number of extractive industry corporations displayed a constructive attitude during the drafting process of the CBCR rules. ${ }^{65}$ The reason seems to be that this industry is characterised by long project cycles, which are coupled with great uncertainty regarding resource prices and project output. Increased transparency acts as a safeguard against reopening negotiations or expulsion after investments have been made in the researchrich countries where they operate. ${ }^{66}$ In turn, it also makes the conversations regarding the contributions - including local infrastructure improvements - that corporate payments make to these countries clearer. In comparison, the logging industry was more vocal against the CBCR rules. ${ }^{67}$ Two reasons can explain the difference in attitude. First, section 1504 of the US Dodd-Frank Act does not cover corporate activities related to the logging of primary forests. Competitors that are listed in the US (but not in the EU) do not have to disclose payments on a CBCR basis. Second - and more importantly - most logging corporations that fall under the CBCR rules are not listed and are smaller than extractive industry corporations are. Competitors of unlisted EU logging corporations are more likely to escape the CBCR rules as they are less likely to have subsidiaries with legal personality in the EEA. ${ }^{68}$ The effect is further amplified because logging corporations are generally less specialised than extractive industry corporations are.

However, it comes as no surprise that the EU has included the logging of primary forests in the $\mathrm{CBCR}$ rules. The $\mathrm{CBCR}$ rules regarding logging complements a number of other initiatives which have been taken in the framework of the FLEGT Action Plan, including the Timber Regulation which requires traders of timber products to exercise due diligence in order to prevent illegal wood from entering into the EU market. ${ }^{69}$ The

\footnotetext{
${ }^{65}$ European Commission, 'Summary report of the Commission's Consultation on Country-by-Country Reporting by Multinational Companies' (2011) $<\mathrm{http}$ ://ec.europa.eu/finance/consultations/2010/financialreporting/index_en.htm> accessed 11 February 2018.

${ }^{66}$ See European Parliament, 'Resolution of 7 October 2010 on Failures in Protection of Human Rights and Justice in the Democratic Republic of Congo' (2010) P7_TA(2010)0350 <http://www.europarl.europa.eu/sides/getDoc.do?pubRef=-//EP//NONSGML+TA+P7-TA-20100350+0+DOC+PDF+V0//EN> accessed 11 February 2018, 42-51.

${ }^{67}$ According to the 2018 review of the CBCR rules which has been conducted at the request of the Commission, logging companies were also the least likely to comply with the CBCR rules. See Porsch and others (n 26) 21.

${ }^{68}$ Commission (n 38) 8.

${ }^{69}$ The FLEGT Action Plan has been developed through the negotiation of bilateral Voluntary Partnership Agreements between the EU and timber exporting countries. Both parties to such agreements commit to putting in place a scheme designed to guarantee that only licensed products from these partner countries will enter the EU. In 2008, the Commission proposed legislation that would require all operators placing timber products on the EU market to put into place systems in order to ensure that their timber is of legal origin. In 2010, the European Parliament voted in support of the European Parliament and Council, Regulation no 995/2010 Laying Down Obligations of Operators who place Timber and Timber Products
} 
EU has taken a leadership role in international environmental politics since the early 1990s to protect the general interests of the whole of Europe and, by extension, the global common good. It is beyond the scope of this article to discuss in-depth the reasons why the EU has taken up a leadership role in environmental matters. ${ }^{70}$ It suffices to note here that the EU's interest in global compliance in environmental matters is much more direct than in human rights matters, due to the interdependency of environmental regimes. ${ }^{71}$

\section{E. A GLOBAL CHARACTER: EMPOWERING THE EITI}

Apart from defining the scope of the CBCR rules in an extensive way, the EU used another strategy to give them a 'global' character. The impact assessment stated that the combined effect of the EU and the US rules would have a major impact on corporations falling outside the CBCR rules (including state-owned corporations in economically developing and emerging countries). ${ }^{72}$ Strengthening multilateral initiatives would ultimately reduce any negative effects vis-à-vis the competitive situation with EEA-based corporations. ${ }^{73}$ The EU relies on two multilateral institutions to achieve these goals.

First, the EU plans to contribute to the 'continued work' of the development of an International Standard by the International Accounting Standards Board (IASB). ${ }^{74}$ The IASB is a private sector organisation established in 1973 that has become the most widely recognised international financial reporting standard-setter in the world as 166 countries either permit or require the use of its standards. The development of an accounting standard for extractive industries by the IASB has been slow. The EU aims to get CBCR on the agenda of the IASB, despite the fact that the IASB stated that CBCR is not within the scope of accounting regulation in its 2006 project on company segmental reporting. ${ }^{75}$

\footnotetext{
on the Market (2010) OJ L 295 to ban illegal timber imports in the EU in a bid to fight climate change, deforestation from the Amazon, Central Africa and Asia, and the loss of revenue to governments. Under this Regulation, all operators who place timber products on the EU market have to exercise due diligence along the supply chain to ensure traceability. Member States are responsible for applying sanctions, ranging from fines to criminal law penalties.

70 There exists a rich literature on this topic. For example, Daniel Kelemen, 'Globalizing European Union Environmental Policy' (2010) 17(3) J.E.P.P., 335, 335-36.

71 Jennifer Shkabatur, 'A Global Panopticon? The Changing Role of International Organisations in the Information Age’ (2011) 33 Mich.J.Int'1 L. 159, 175.

72 Commission (n 38) 35-36.

73 ibid 26,35 and 36.

${ }^{74}$ Ibid 43-48; Recital 53 Directive 2013/34/EU.

75 International Accounting Standards Board, 'International Financial Reporting Standards 8 Operating Segments', <www.iasb.org> accessed 11 February 2018.
} 
Second, the CBCR rules would serve as an incentive to extend EITI's scope to all resource-rich countries. ${ }^{76}$ The EITI is a multilateral initiative that promotes revenue transparency in oil, gas, mining (and logging) sectors in order to reduce tax avoidance and corruption in the extractive sector. It brings together stakeholders from government, civil society, investors and corporations into a national multi-stakeholder group, requesting governments to publish the revenues effectively received from corporations with activities in exploration and production in extractive activities (and logging). ${ }^{77}$ While the EITI is a voluntary initiative, participation in the process is mandatory for all extractive sector operators (including state-owned enterprises) once a country has endorsed the initiative, thereby creating a level playing field for all extractive operators. As many resource-rich countries were reluctant to join the EITI, the Commission found it necessary to 'accelerate' the process by which payments to governments in developing resource-rich countries would be characterised as falling into the public domain. ${ }^{78}$ It noted that in 2011, eight years after the EITI initiative had started, only nine out of fifty countries designated as resource-rich had joined the EITI. Some top exporters of hydrocarbons such as Algeria, Angola and Venezuela were not EITI-compliant or candidate countries. Only one country, Liberia, opted to extend the EITI to the logging sector at the time. ${ }^{79}$ The Commission predicted that the significant increase in the total level of data on payments to governments entering the public domain by the complementary efforts of the US and the EU would put pressure on governments of resource-rich countries to account for how all revenues derived from extractive activities and logging of primary forests have been spent.

While the CBCR rules empower the EITI, they also go further than the EITI in two respects. According to the impact assessment, the CBCR rules were more adequate than the EITI as governments cannot easily strip them of their impact. First, governments do not decide on the materiality level for reporting payments or company participation under the CBCR rules. Under the EITI, governments can autonomously decide on the size of payment or the threshold size of company operations below which they are excluded from the process for reasons of cost/benefit. Second, the obligation to publish

\footnotetext{
76 Commission, 'Proposal for Directive on Transparency Requirements for Listed Companies and Proposals on Country-by-Country Reporting - Frequently Asked Questions' (2011) MEMO/11/734, para 16.

${ }^{77}$ Commission (n 38) 35-36.

78 ibid 19.

${ }^{79}$ ibid 40.
} 
all information does not ultimately lie with governments, but with corporations under the CBCR rules. While corporations have to provide fully disaggregated statements that apply international auditing standards under the EITI, the government can opt to publish the data in an aggregated form in the public EITI report. The conclusion that the Commission wanted to have a definite say in how country-by-country reporting should happen is further supported by the fact that establishing a multilateral framework was not seen as an option as it 'would be the result of negotiation and compromise between the EU and its international partners, and the outcome of such negotiations would be difficult to foresee'. 80

The presented findings fit with the body of research on the use of 'extraterritorial extension' mechanisms by the EU in response to the 2007 global financial crisis, which had such a profound impact on the Eurozone. ${ }^{81}$ In order to increase integrity and transparency of financial markets, the EU regulated conduct taking place outside its borders but which is connected with its territory. It has been proposed that, in so doing, the EU exercises its regulatory power to develop the institutional architecture of international organisations and to determine the extent and terms of global governance. ${ }^{82}$ Prior to establishing rules with an extraterritorial component which fit with its 'business and human rights' policy, the EU took measures in other areas, such as animal welfare, data protection and the environment. It is useful to give another example of ‘extraterritorial extension' mechanisms here. EU Regulation 421/2014 imposed a temporary scheme, which ran from 2013 to 2016 for greenhouse gas emissions from commercial aviation activities. ${ }^{83}$ While this Regulation was not generally applicable to aircrafts registered in non-EU countries and flying over third countries or the high seas, emission allowances for the full trajectory of flights which arrived at or departed from an aerodrome situated in the territory of an EU Member State needed to be monitored, reported and surrendered, including for the parts of the flight above the high seas and in the airspace of non-EU countries. This Regulation had the explicit ambition to combat

\footnotetext{
80 ibid 21-22.

81 Joanne Scott, 'Extraterritoriality and Territorial Extension in EU Law' (2013) 62 The American Journal of Comparative Law 87, 134.

82 Wade Jacoby and Sophie Meunier, 'Europe and the Management of Globalization' (2010) 17(3) J.E.P.P. 299, 306.

83 European Parliament and Council Regulation 421/2014 Amending Directive 2003/87/EC Establishing a Scheme for Greenhouse Gas Emission Allowance Trading within the Community, in View of the Implementation by 2020 of an International Agreement Applying a Single Global Market-based Measure to International Aviation Emissions Text with EEA Relevance [2014] OJ L129/1.
} 
climate change by securing a future international agreement to control emissions from aviation by $2020 .^{84}$ In particular, it aimed to empower the International Civil Aviation Organization (ICAO) to adopt specific measures to control international aviation emissions.

While the compatibility of autonomous measures with an extraterritorial component with international law has not been definitively proclaimed, the Court of Justice of the European Union (CJEU) considers such rules to be consistent with customary international law. The CJEU weighed in on this issue in the Air Transport Association of America and Others $v$ Secretary of State for Energy and Climate Change case (ATAA case) which was brought by a number of American airlines in relation to Regulation 421/2014. ${ }^{85}$ It held that situations in which there is some territorial link with EU Member States fall squarely within EU's jurisdiction. ${ }^{86}$ It is worth quoting in full the relevant paragraph of this judgment:

[T] he European Union legislature may in principle choose to permit a commercial activity, in this instance air transport, to be carried out in the territory of the European Union only on condition that operators comply with the criteria that have been established by the European Union and are designed to fulfil the environmental protection objectives which it has set for itself, in particular where those objectives follow on from an international agreement to which the European Union is a signatory. ${ }^{87}$

Regulation 421/2014 was not well received by other countries. The US issued a blocking legislation preventing US-based airlines from participating in the EU Scheme and China threatened to stop its agreements with the European Aeronautic Defence and Space Company. ${ }^{88}$ In response, the EU adopted a 'stop the clock' Regulation to

\footnotetext{
84 ibid Recital 2.

85 Case C-366/10 Air Transport Association of America and Others v Secretary of State for Energy and Climate Change [2011] ECR I-13755 paras 122-23.

${ }^{86}$ Similarly, the ECJ ruled in Case C-592/14 European Federation for Cosmetics Ingredients $v$ Secretary of State for Business, Innovation and Skills [2016] EU:C:2016:703 that prohibits the placing on the market of products whose ingredients have been subject to animal testing as set out in art 18(1) European Parliament and Council, Regulation No. 1223/2009 on Cosmetic Products [2009] OJ L 342/59 is lawful. The ECJ reasoned that any other application would make it easy for cosmetics companies to do their animal testing outside the EU (para 41). See Jessica Lawrence, 'The Extraterritorial Reach of EU Animal Welfare Rules (Again): Case C-592/13 European Federation for Cosmetic Ingredients’ (2016) European Law Blog $<$ https://europeanlawblog.eu/2016/11/16/the-extraterritorial-reach-of-eu-animal-welfare-rules-again-casec-59214-european-federation-for-cosmetic-ingredients/> accessed 11 February 2018.

${ }^{87}$ ATAA case, para 128 referring to TFEU, art 191(2).

${ }^{88}$ European Union Emissions Trading Scheme Prohibition Act 2011 (US).
} 
temporarily suspend Regulation 421/2014 under the condition that a multilateral solution to address emissions from aviation would be found within ICAO by the end of $2016 .{ }^{89}$ The ICAO adopted the Carbon Offsetting and Reduction Scheme for International Aviation (CORSIA) in $2016 .{ }^{90}$ It thus appears that the EU has succeeded in securing a multilateral agreement. However, this agreement turned out not to be as stringent as the EU might have hoped. ${ }^{91}$ The CORSIA will only apply to emissions growth and not to existing emission levels. In addition, the CORSIA has yet to establish a system of sanctions for non-compliance and enforcement criteria. There has been some debate between the EU institutions about what an appropriate reaction to the CORSIA would be. Ultimately, a new Regulation was adopted in the 2017 which gives the ICAO more time (until the end of 2021) to issue stricter measures.

The ATAA case illustrates that the EU can try to accommodate changes in the global rulemaking landscape, but must respect substantive limits. Unilateral rule-making denies the reality of different experiences and needs in other countries. Criticisms of neocolonialism, interference in other countries' sovereignty and protectionism are apposite. In addition, EU's global efforts continually interact with the strategies of other countries. $^{92}$

The exercise of extraterritorial extensions as proclaimed in the CBCR rules could have been controversial if other countries had regarded it as interference against their sovereign right to regulate corporations within their own borders and to pursue their own economic, social and cultural interests. ${ }^{93}$ However, they did not raise major problems, as

\footnotetext{
${ }^{89}$ European Parliament and Council Regulation 421/2014 Amending Directive 2003/87/EC Establishing a Scheme for Greenhouse Gas Emission Allowance Trading within the Community, in View of the Implementation by 2020 of an International Agreement Applying a Single Global Market-based Measure to International Aviation Emissions Text with EEA Relevance (2014) OJ L129/1; Cédric Ryngaert and Marieke Koekkoek, 'Extraterritorial Regulation of Natura Ressources: Functional Approach' in Jan Wouters and others (eds), Global Governance through Trade EU Policies and Approaches (Elgar 2015) 245, 247.

90 International Civil Aviation Organization, 'Consolidated Statement of Continuing ICAO Policies and Practices Related to Environmental Protection - Global Market-based Measure (MBM) Scheme' (2016) Resolution A39-3.

91 European Parliament and Council Regulation 2017/2392 amending Directive 2003/87/EC to Continue Current Limitations of Scope for Aviation Activities and to Prepare to Implement a Global Market-Based Measure from 2021 (2017) OJ L350/7; X, 'Clash Looms Between EU Institutions on How Long to Stop the Clock on Scope of the Aviation EU ETS' (2017) Green Air Online <http://www.greenaironline.com/news.php?viewStory=2406> accessed 11 February 2018.

92 Alberta Sbragia, 'The EU, the US and Trade Policy: Competitive Interdependence in the Management of Globalization' 17(3) J.E.P.P. 368.

93 Daniel Augenstein, 'Study of the Legal Framework on Human Rights and the Environment Applicable to European Enterprises Operating Outside the European Union' (2010) <https://www.academia.edu/1366068/study_of_the_legal_framework_on_human_rights_and_the_enviro
} 
the US had already adopted a regulation which required corporations listed in the US to begin country-by-country reporting in 2019 under section 1504 of the US Dodd-Frank Act. It is also worth noting in this regard that the Commission itself claimed that the CBCR rules would 'only be a breach of other states national sovereignty where disclosure of payments is prohibited by local laws in third states' ${ }^{94}$ Following an intervention of the European Parliament, the proposed exemption to only require that the name of countries having criminal anti-disclosure in place would be disclosed - instead of CBCR payments - has also been deleted. ${ }^{95}$ The European Parliament deemed that such exemption would protect tyrants and, therefore, overshoot the objective of the CBCR rules. ${ }^{96}$

The current situation is very different. Although the US Dodd-Frank Act became law in 2010 under the Obama Administration, the US Securities and Exchange Commission (US SEC) could implement Section 1504's disclosure provisions only in $2016 .^{97}$ Rule $240.13 q-1$ would have required most corporations to begin disclosing payments in 2019. However, on 14 February 2017, the Republican-controlled US Congress removed this Rule in a joint resolution that was signed by President Trump under the Congressional Review Act. ${ }^{98}$ Removing the CBCR obligation is part of the Trump Administration's efforts to reduce the regulatory burden facing corporations. In a statement, it was explained that Rule 240.13q-1:

[...] would impose unreasonable compliance costs on American energy companies that are not justified by quantifiable benefits. Moreover, American

\footnotetext{
nment_applicable_to_european_enterprises_operating_outside_the_european_union_study_for_the_euro pean_commission_entr_09_045_2010_> accessed 11 October 2019 12-13.

94 The impact assessment notes, for example, that the Angolan Ministry of Petroleum issued a Directive (Despacho) 385/06 in 2006 which states that 'Companies active (in the petroleum industry) in the country are prohibited from divulging any information without the formal authorisation of the Ministry of Petroleum'. See Commission (n 38) 39-40.

95 The 2018 review of the CBCR rules - commissioned by the Commission - explains, for example, that the amounts declared by the Angolan authorities differ by more than USD 100 million from the data available from the country-by-country report of France's largest energy company Total. The Angolan government reportedly dismissed these inconsistencies by alleging that they are a result of 'incompetence and errors in accounting' as described in Porsch and others (n 26) 5.

96 European Parliament, 'Oil, Gas, Mineral and Logging Firms Obliged to Disclose Payments to Governments’ (2013) <http://www.europarl.europa.eu/news/en/press-room/20130607IPR11387/oil-gasmineral-and-logging-firms-obliged-to-disclose-payments-to-governments> accessed 12 September 2018.

97 US SEC's Resource Extraction Payment Disclosure (81 FR 49426, 27 July 2016) Rule 240.13q-1.

98 Public Law 115-4 2017 (US). The Congressional Review Act 104-121 1996 (US) allows Congress to adopt joint resolutions to overrule end-of-term regulations with a simple majority vote).
} 
businesses could face a competitive disadvantage in cases where their foreign competitors are not subject to similar rules. ${ }^{99}$

The US rules will be re-drafted by the US SEC under Section 1504 of the US Dodd-Frank Act, but it is likely that its replacement will meet the same standard, as the Trump Administration has vowed to protect commercially sensitive information as well as governments that prohibit disclosure of their projects. ${ }^{100}$ Note that Rule $240.13 q-1$ (d) already allowed US listed corporations to apply for 'exemptive relief' when governments prohibit the publication of country-by-country reports. The US SEC had adopted this rule in response to a lawsuit that had been brought by the American Petroleum Institute in the US District Court for the District of Columbia. ${ }^{101}$

Regardless of what will happen next in the US, country-by-country reporting seems to be here to stay. It appears that the EU has been successful in creating CBCR rules, which do not have an overly negative impact on EU based corporations. Three observations support this hypothesis. First, Norway and Canada have adopted CBCR obligations that resemble EU's initiative. ${ }^{102}$ Second, the number of countries that have joined the EITI has increased significantly. At the time of the impact assessment in 2011, only nine out of the fifty countries considered hydrocarbon or mineral-rich by the International Monetary Fund were EITI compliant. Today, more than thirty of these are compliant with the 2011 version of the EITI. Third, European extractive companies have not reported that they suffer material damages or losses of opportunities due to the introduction of the CBCR requirements according to the 2018 review of the CBCR rules which has been conducted at the request of the Commission. ${ }^{103}$

99 Donald Trump, 'Statement of Administration Policy: H.J. Res. 38, H.J. Res. 36, H.J. Res. 41, H.J. Res. 40, \& H.J. Res. 37’ (2017) <http://www.presidency.ucsb.edu/ws/?pid=123145> accessed 6 July 2018. 100 ibid.

101 American Petroleum Institute v US SEC, 953 F. Supp. 2d 5 (D.D.C., 2013); US SEC, 'Disclosure of Payments by Resource Extraction Issuers’ (2016) <https://www.sec.gov/rules/final/2016/34-78167.pdf> accessed 28 June 2019202.

102 Forskrift om Land-For-Land Rapportering 2013 (NO); Extractive Sector Transparency Measures Act 2014 (CA). Note that the China Chamber of Commerce of Metals, Minerals and Chemicals Importers and Exporters - a subordinate unit of the Ministry of Commerce of China - issued the Guidelines for Social Responsibility in Outbound Mining Investments. While these Guidelines are not binding, they have been recognised as a major commitment of the Chinese government. See for example Peter Dolega and Doris Schüler, 'European Policy Brief. China's Approach Towards Responsible Sourcing' (2018) <http://stradeproject.eu/fileadmin/user_upload/pdf/STRADE_PB_03_2018_China_responsible_sourcing. pdf $>$ accessed 27 June 2019 3, 6; Audrey Weerts, Sophie Wintgens and Jean Claude Mputu, 'Les Strategies Americaine, Européenne et Chinoise Face aux Minerals des Conflits: Défis ou Opportunités pour la RDC?' (2014-2015) L'Afrique des Grands Lacs 195, 206-07.

103 Porsch and others (n 26) 13. 
It is, however, also likely that the EU will not further strengthen its CBCR rules in the oil, gas, mining and logging sector in the immediate future by, for example, imposing a mandatory audit. ${ }^{104}$ Fortunately, some EU Member States - such as Belgium - require such an audit when they transposed the CBCR rules into national law. ${ }^{105}$ It can be predicted that these EU Member States will be supporters of similarly strict obligations in the EEA. The creation of a level playing field in the EEA would enable states to make sure that their respective corporate nationals would not suffer (perceived and real) shortterm corporate disadvantages vis-à-vis other EEA Member States. Callaghan refers to such support as a 'constrain-thy-neighbour' effect. ${ }^{106}$

\section{F. CONCLUSION}

This article has identified a tension between long-term and short-term economic EU interests. In the long run, EU-based corporations might benefit from 'business and human rights' regulation to secure access to energy resources and critical raw materials which are needed to innovate value propositions. The emerging economies of China and India are seen as a particular threat as they emerged as major buyers of energy resources and critical raw materials, a trend which has accelerated in the aftermath of the global financial crisis. In the short run, 'business and human rights' regulation might, however, have an immediate impact on the competitiveness of corporations based in the EEA. Mirroring legal developments in the US, the EU ultimately decided to take a long-term approach while attempting to minimise the impact on the competitiveness of corporations based in the EEA. The EU minimised such impact by giving the CBCR rules a 'global' character. The CBCR rules require all large oil, mining, minerals and logging corporations listed in the EEA - even if they are not incorporated under the laws of an EEA Member State - to report on payments made to governments regardless of their place of incorporation. In so doing, the EU has tried to strengthen the EITI while at the same time having a definite say as to how country-by-country reporting should happen on a global scale.

A similar analysis can be conducted for the other sector-specific regulation which contributes to the EU's 'business and human rights' policy, the Conflict Minerals

\footnotetext{
104 ibid 64-73.

105 Arts. 3:7, 3:8, 3:33 and 3:34 Wetboek van Vennootschappen en Verenigingen 2019 (BE).

106 Helen Callaghan, 'Constrain-Thy-Neighbor Effects as a Determinant of Transnational Interest Group Cohesion’ (2010) 44(7) Comp.Pol.Stud. 910, 923.
} 
Regulation. This Regulation requires EU-based importers of the largest volumes of ores and concentrates containing tin, tantalum, titanium and gold - scarce materials on which EU Member States are highly dependent to innovate product value chains - to exercise due diligence over their suppliers in conflict-affected and high risk areas outside the EU. ${ }^{107}$ Smelters and refiners in non-EU countries are not de jure bound but they will be de facto bound if they want to continue their business relationships with EU-based importers. In this case, the EU relies on its market power as a relatively large importer of minerals - accounting for one-third of global trade volumes - to strengthen the OECD Due Diligence Guidance for Responsible Supply Chains of Minerals from conflictaffected and high-risk areas while at the same time having a definite say on how these industries should function. ${ }^{108}$

Finally, it is worth noting that the EU was not able to overcome competitiveness concerns in the Non-Financial Reporting Directive, the only sector-wide initiative which contributes to EU's 'business and human rights' policy. A number of EU Member States that had already taken similar legislation at the national level pushed this Directive. Although Commissioner Michel Barnier noted that the Commission tried to include 'large companies listed in EU-regulated markets, but registered in Third World countries' in the scope of this Directive, ${ }^{109}$ this option was ultimately not retained. ${ }^{110}$ Instead, the Commission made 'substantial efforts to ensure that the administrative burden on EU companies was kept as minimal as possible'. ${ }^{111}$ The Directive does not determine key performance indicators nor auditing obligations.

\footnotetext{
${ }^{107}$ Late in the negotiations, some EU Member States successfully pushed for the inclusion of a series of import thresholds in Annex I to the Conflict Minerals Regulation.

108 OECD, OECD Due Diligence Guidance for Responsible Supply Chains of Minerals from ConflictAffected and High risk Areas (2 $2^{\text {nd }}$ edn, OECD Publishing 2013).

109 Global Reporting, 'Fast Forward to a Transparent and Sustainable Future' (2014) <https://www.globalreporting.org/information/news-and-press-center/Pages/fast-forward-to-atransparent-and-sustainable-future-.aspx> accessed 11 February 2018.

110 The Directive is only applicable to public interest entities in the sense of art 2 Accounting Directive 2013/34/EU that meet certain size criteria. (Arts 19a and 29a Directive 2014/95/EU referring to art 2 Directive 2013/34/EU). The most likely reason is that this word has created a disincentive for such Directive 2014/95/EU corporations to be listed in the EU. Stock exchange markets must be supported with adequate economic incentives in order to attract investment and maintain vibrancy as they have reached a sufficiently high level of maturity and internationalization that they can host companies from anywhere in the world. Extra EU regulation would stand in the way of attracting non-EU corporations to list (or stay listed) in the EU.

${ }^{111}$ Barnier (n 58) 18.
} 